\title{
STATIC CORROSION TEST OF POROUS IRON MATERIAL WITH POLYMER COATING
}

\author{
L. Markušová-Bučková, R. Oriňaková, A. Oriňak, R. Gorejová, M. Kupková, \\ M. Hrubovčáková, M. Baláž, K. Kovál'
}

\begin{abstract}
At present biodegradable implants received increased attention due to their use in various fields of medicine. This work is dedicated to testing of biodegradable materials which could be used as bone implants. The samples were prepared from the carbonyl iron powder by replication method and surface polymer film was produced through sol-gel process. Corrosion testing was carried out under static conditions during 12 weeks in Hank's solution. The quantity of corrosion products increased with prolonging time of static test as it can be concluded from the results of EDX analysis. The degradation of open cell materials with polyethylene glycol coating layer was faster compared to uncoated Fe sample. Also the mass losses were higher for samples with PEG coating. The polymer coating brought about the desired increase in degradation rate of porous iron material.
\end{abstract}

Keywords: biomaterial, degradation, porous structure

\section{INTRODUCTION}

Degradable biomaterials represent a new category of materials [1]. The role of materials is to replace damaged tissues and support their function [2]. They should form a structural support to the injured tissues, promote cellular proliferation and gradually degrade with increasing tissue repair [1]. Temporary implant devices can avoid the chronic inflammation, stress shielding, and reduce the number of operational interventions compared to permanent implants [3]. The application of these biodegradable implants is studied in the field of orthopaedics, cardiosurgery and paediatrics [4].

Candidates for the production of biodegradable implants are some polymers [5] and metals [6]. The most studied polymers for this purpose are polyesters [5] and magnesium [7], iron and zinc [8] are examined metals. Route of polymer degradation is hydrolysis [5] and metals are degraded in the process of corrosion [9]. The metals have superior mechanical properties compared with the polymers, therefore, metals are a better choice for orthopedic applications [10].

\footnotetext{
Lucia Markušová-Bučková, Renáta Oriňaková, Andrej Oriňak, Radka Gorejová: Department of Physical Chemistry, Faculty of Science, P.J. Šafárik University, Moyzesova 11, SK-04154 Košice, Slovak Republic

Miriam Kupková, Monika Hrubovčáková, Karol Kovál': Institute of Materials Research, Slovak Academy of Science, Watsonova 47, SK-04353 Košice, Slovak Republic

Matej Baláž, Institute of Geotechnics, Slovak Academy of Science, Watsonova 47, SK-04353 Košice, Slovak Republic
} 
In addition to sufficient mechanical properties of implantable devices is also required their acceptable biocompatibility. Biocompatibility is an important feature determining the possibility of their use as implant devices. Biological compatibility is a material property, it allows the implant to exist in a physiological environment, without damaging it in some way. The biocompatibility is the ability of the implant to provide the intended function with the desired degree of integration in the host without causing any adverse local or systemic effects [11]. Biocompatibility of degradable device is highly dependent on the degradation behavior of the material used. Implants may not operate thrombogenic, hemolytic, carcinogenic, cytotoxic, mutagenic, must not alter blood proteins and encourage the adverse effects of the immune system. These requirements apply not only to the material but also to its degradation products. The toxic effect of the substances is undesirable, at any level of the organism (cells, tissues, genetic information etc.) [12].

Among the metal elements, iron is commonly used in development of new biodegradable materials [13]. Fe is an important component of the human body. It is part of many enzymes and proteins and moreover has similar mechanical properties to bone. Degradable implants based on iron have a low degradation rate that is necessary to adjust because slow degradation can cause the same problems as permanent implant devices, such as chronic inflammation, creation of thrombus etc. [14]. The required corrosion rate of the orthopedic implants is $\sim 0.5 \mathrm{~mm} /$ year in the simulated body fluid at $37^{\circ} \mathrm{C}$ [8].

The final structure of prepared implant depends on specific application. It is important that the structure of implant material followed the appearance of tissue to replace. Open cell structure of implant devices is the optimal for porous bone tissue [15]. Simply and effective method that can be used to form this structure is powder metallurgy. The final product has near-net shape with uniform morphology [16].

In this work the corrosion properties of iron based materials with polyethylene glycol coating were examined with regard to their use as potential orthopaedic implants. The powder metallurgy method was used to prepare metallic cellular structure. Corrosion rate of produced porous structures was determined from immersion test in simulated body fluid.

\section{EXPERIMENTAL PROCEDURE}

\section{Material preparation}

The carbonyl iron powder (CIP) fy BASF (type CC d50 $3.8-5.3,3.8-5.3 \mu \mathrm{m}$ ), with composition $99.5 \% \mathrm{Fe}, 0.05 \% \mathrm{C}, 0.01 \% \mathrm{~N}$ and $0.18 \% \mathrm{O}$, was used as basic material. The cellular samples were prepared by impregnating the polyurethane foam (PUR) (Filtren TM 25133) with the suspension consisting of $7 \mathrm{~g}$ carbonyl iron powder and $6 \mathrm{ml}$ ultrapure water with $200 \mathrm{mg}$ dissolved gelatine (Sigma-Aldrich, USA). The PUR impregnated with iron powder was sintered in a tube furnace Aneta 1 at $450^{\circ} \mathrm{C}$ for 2 hours in nitrogen atmosphere to remove PUR and then at $1120^{\circ} \mathrm{C}$ for 1 hour in reduction atmosphere $(90 \%$ $\mathrm{N}_{2}, 10 \% \mathrm{H}_{2}$ ) to obtain final open cell structure. The polyethylene glycol (Sigma-Aldrich, USA) coating layer was produced through sol-gel process on the surface of sintered $\mathrm{Fe}$ foam. Solutions containing 5, 10 or 15 wt.\% of PEG in 96\% ethanol (Mikrochem spol. s r.o., Slovakia) were stabilized at laboratory temperature for one day. Subsequently the ultrasonically cleaned Fe materials were dipped into the solutions during 3 hours at laboratory temperature and then the coated iron specimens were dried for 3 hours at $45^{\circ} \mathrm{C}$. 


\section{Static immersion test}

Sintered samples were weighed before corrosion test to obtain initial weights $\left(m_{i}\right)$ and then the samples were ultrasonically cleaned in acetone and ethanol for 10 minutes each. Samples were immersed in $10 \mathrm{ml}$ of simulated body fluid with composition $8 \mathrm{NaCl}$,

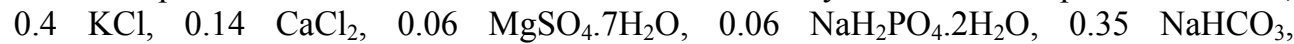
1.00 Glucose, $0.60 \mathrm{KH}_{2} \mathrm{PO}_{4}$ and $0.10 \mathrm{MgCl}_{2} \cdot 6 \mathrm{H}_{2} \mathrm{O}$ (in g/l) (Fig. 1). The static test was carried out for 12 weeks and the temperature was kept at $37^{\circ} \mathrm{C}$. After every 7 days of corrosion the experimental samples were ultrasonically cleaned in ethanol and distilled water for 10 minutes each, air dried and weighed. Corrosion rate was calculated using the formula:

$$
C R=\frac{m_{i}-m_{f}}{A t}
$$

where $C R\left[\mathrm{mg} / \mathrm{m}^{2}\right.$ day $]$ is corrosion rate, $m_{f}[\mathrm{mg}]$ is the final mass after corrosion, $A\left[\mathrm{~m}^{2} / \mathrm{mg}\right]$ is the initial specific surface area of iron sample before corrosion and $t$ [day] is the immersion time [17].

The specific surface area values of experimental samples were calculated by the Brunauer-Emmett-Teller (BET) theory. The amount of corrosion products in immersion medium was obtained using the atomic absorption spectrometry (AAS).

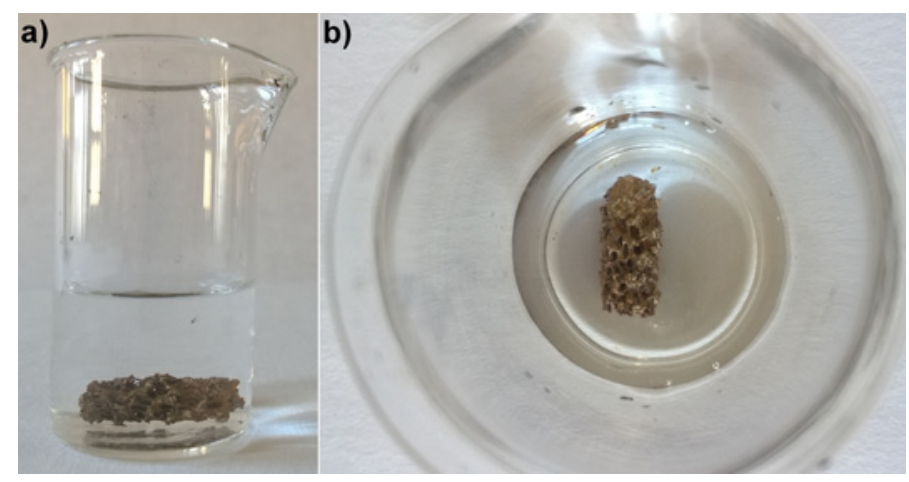

Fig.1. Cellular iron sample in Hank's solution during the static immersion test: a) top view; b) side view.

\section{RESULTS AND DISCUSSION}

The appearance of sintered iron specimens with PEG coating was similar to the structure of PUR foam. The deposition of PEG coating layer caused smoothing of rough texture of iron samples. Sintered cellular materials contained spherical macropores with pore size $350-1700 \mu \mathrm{m}$. Immersion of specimens into Hank's solution led to destroying of the original porous structure. Figure 2 shows micrographs of experimental specimens before degradation and after 12 weeks of static test in simulated body fluid at $37^{\circ} \mathrm{C}$. After 12 weeks of degradation the porous structure was totally eroded, pore walls disappeared and corrosion products were formed on the surface of prepared samples.

The surface properties of prepared experimental materials were investigated by BET method and the $\mathrm{S}_{\mathrm{BET}}$ (specific surface area) values are listed in Table 1. The $\mathrm{S}_{\mathrm{BET}}$ values increase as the following: Fe, Fe +5 wt.\% PEG, Fe + 10 wt.\% PEG, Fe + 15 wt.\% PEG. The polymer coating caused an increase in the specific surface area values of samples 
with PEG film compared to the uncoated specimen. It can be seen that the highest specific surface area was found in the Fe +15 wt.\% PEG.

Tab.1. The specific surface area values of uncoated and PEG coated experimental samples.

\begin{tabular}{|c|c|}
\hline Sample & $\mathrm{S}_{\mathrm{BET}}\left[\mathrm{m}^{2} \cdot \mathrm{g}^{-1}\right]$ \\
\hline $\mathrm{Fe}$ & 0.48 \\
\hline $\mathrm{Fe}+5 \mathrm{wt} . \%$ PEG & 0.80 \\
\hline $\mathrm{Fe}+10 \mathrm{wt} . \%$ PEG & 0.91 \\
\hline $\mathrm{Fe}+15 \mathrm{wt} \%$ PEG & 2.88 \\
\hline
\end{tabular}
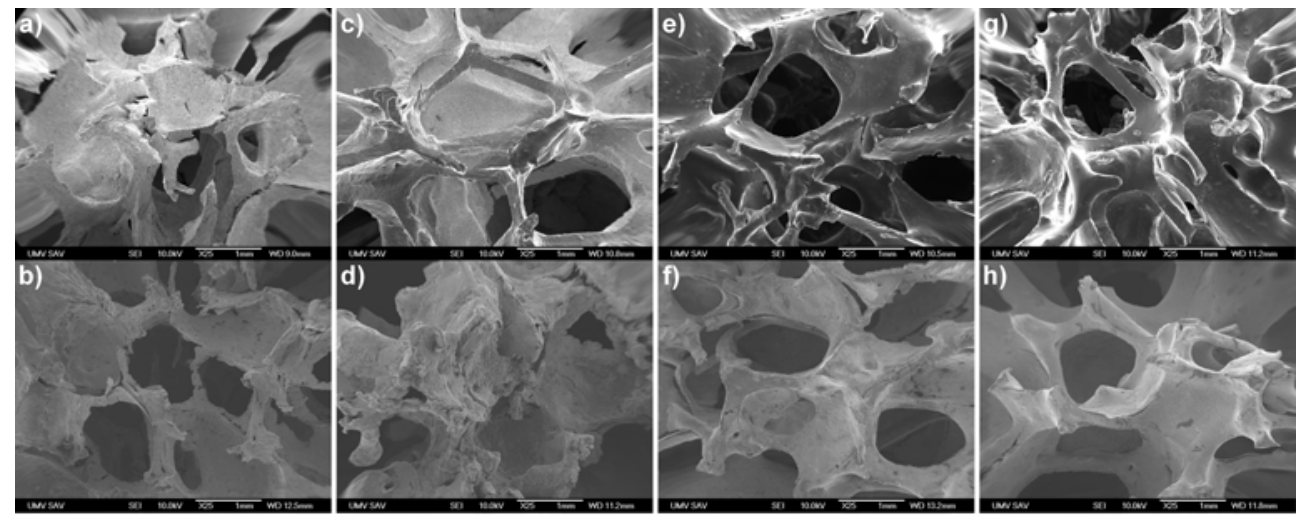

Fig.2. Sintered iron samples before (a, c, e, g) and after 12 weeks of immersion test (b, d, f, h): Fe sample (a, b); Fe + 5 wt.\% PEG (c, d); Fe + 10 wt.\% PEG (e, f); Fe + 15 wt.\% PEG $(\mathrm{g}, \mathrm{h})$.

The content of degradation products on the surface of uncoated and PEG coated specimens was determined by energy-dispersive X-ray (EDX) analysis. Amount of degradation products is summarised in Table 2. Increase in oxygen amount indicates the accumulation of corrosion products from 4 to 12 week of the immersion in Hank's solution for all samples. The quantity of degradation products increases with the amount of the PEG coating and with the time of immersion in Hank's solution. The highest corrosion product amounts are on the material surfaces after 12-week immersion for all samples. Figure 3 shows the mass losses depending on the time of immersion in simulated body fluid. The fastest degradation throughout the first 4 weeks was observed for the sample with $15 \mathrm{wt} . \%$ PEG. Slight increase in degradation rate of the sample with $10 \mathrm{wt} . \%$ PEG was registered in course of remaining time of immersion. The mass losses for coated structures were approximately two times higher than that for uncoated Fe material. The values of mass losses obtained from static immersion test are referred in Table 3. The more significant mass changes are observed in the samples coated with PEG than iron sample. The mass loss increases with the amount of polymer on the surface of a porous structure.

Released iron content of the samples was determined by AAS. The amount of the corrosion products in Hank's solution after static immersion test are listed in Table 4. The values of iron concentration in simulated body fluid increase from the fourth to twelfth week of immersion. The highest amounts of Fe in Hank's solution were observed for uncoated sample and among polymer coated materials the most iron released was measured for $\mathrm{Fe}+15$ wt. $\%$ PEG. 
Tab.2. Results of EDX analysis on the surface of uncoated and PEG coated samples after every four weeks of immersion in Hank's solution.

\begin{tabular}{|c|c|c|c|c|c|}
\hline \multirow{3}{*}{$\begin{array}{c}\text { Time of } \\
\text { corrosion } \\
\text { [week] }\end{array}$} & \multirow[b]{3}{*}{ Element } & \multicolumn{4}{|c|}{ Sample } \\
\hline & & $\mathrm{Fe}$ & $\begin{array}{c}\mathrm{Fe}+5 \mathrm{wt} . \% \\
\text { PEG }\end{array}$ & $\begin{array}{c}\mathrm{Fe}+10 \mathrm{wt} . \% \\
\text { PEG }\end{array}$ & $\begin{array}{c}\mathrm{Fe}+15 \\
\text { wt.\% PEG }\end{array}$ \\
\hline & & wt. $\%$ & wt. $\%$ & wt. $\%$ & wt. $\%$ \\
\hline \multirow[b]{3}{*}{4} & $\mathrm{Fe} \mathrm{K}$ & 64.83 & 63.34 & 60.57 & 61.55 \\
\hline & $\mathrm{C} \mathrm{K}$ & 3.10 & 3.76 & 5.67 & 4.29 \\
\hline & $\mathrm{OK}$ & 32.07 & 32.90 & 33.76 & 34.16 \\
\hline \multirow[b]{3}{*}{8} & $\mathrm{Fe} \mathrm{K}$ & 86.59 & 67.33 & 68.11 & 80.72 \\
\hline & $\mathrm{C} \mathrm{K}$ & 0 & 0 & 0 & 0 \\
\hline & $\mathrm{OK}$ & 13.41 & 32.67 & 31.87 & 19.28 \\
\hline \multirow[b]{3}{*}{12} & $\mathrm{Fe} \mathrm{K}$ & 66.65 & 88.61 & 87.41 & 92.22 \\
\hline & $\mathrm{C} \mathrm{K}$ & 0 & 0 & 0 & 0 \\
\hline & $\mathrm{OK}$ & 33.35 & 11.39 & 12.59 & 7.78 \\
\hline
\end{tabular}

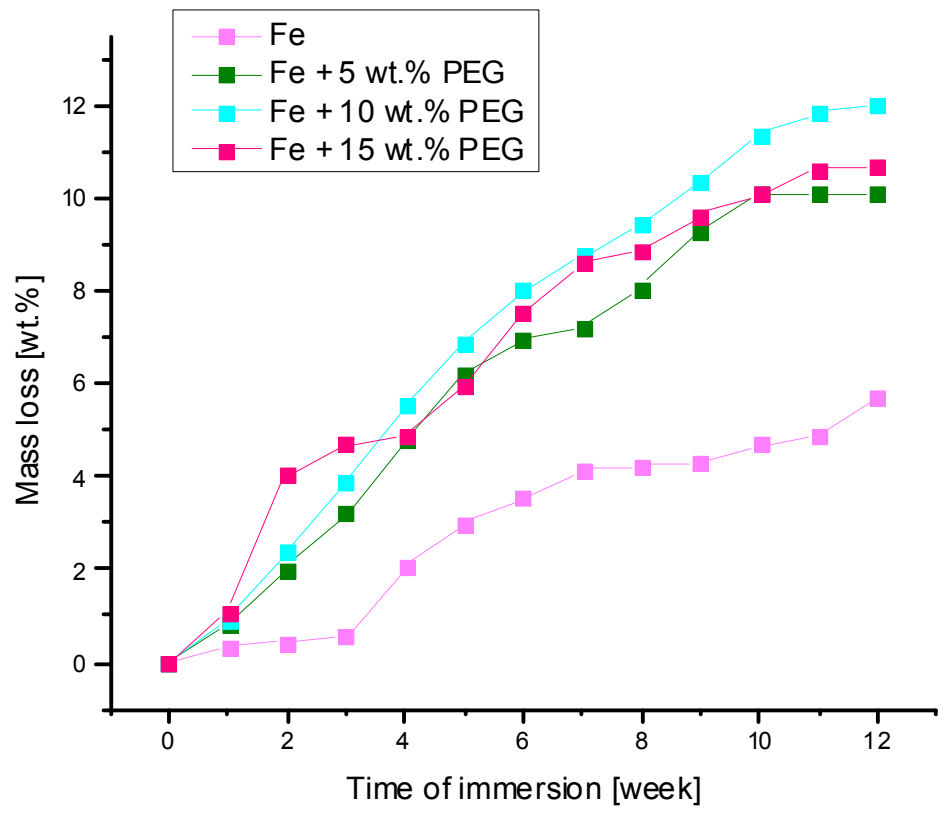

Fig.3. The mass loss during immersion in Hank's solution for 12 weeks for uncoated and PEG coated iron materials.

The values of corrosion rate determined from immersion test were calculated using the formula (1). The corrosion rates are summarized in Table 5. The degradation rates after 12 weeks of immersion in Hank's solution were $1.420 \mathrm{mg} / \mathrm{m}^{2}$ day, $1.526 \mathrm{mg} / \mathrm{m}^{2}$ day, 1.608 $\mathrm{mg} / \mathrm{m}^{2}$ day, and $0.460 \mathrm{mg} / \mathrm{m}^{2}$ day, for Fe, Fe +5 wt. $\%$ PEG, Fe +10 wt. $\%$ PEG and Fe + 15 wt.\% PEG sample, respectively. These rates are in contrast with the results of other 
measurements, especially the value of $\mathrm{Fe}+15$ wt.\% PEG specimen. The reason for this result is a big difference in specific surface area of individual samples (Table 1). The degradation rates calculated on the weight of Fe structures in twelfth week of corrosion were $0.787 \mathrm{mg} /$ day for Fe, $1.404 \mathrm{mg} /$ day for Fe $+5 \mathrm{wt} . \% \mathrm{PEG}, 1.688 \mathrm{mg} /$ day for Fe +10 wt.\% PEG and $1.523 \mathrm{mg} /$ day for Fe +15 wt.\% PEG specimen. It can be seen that the corrosion rate of Fe materials with 10 and 15 wt.\% PEG were the highest.

Tab.3. The values of mass losses of iron based structures during 12-week static immersion test.

\begin{tabular}{|c|c|c|c|c|c|c|c|c|}
\hline Week & \multicolumn{4}{|c|}{ Mass [mg] } & \multicolumn{4}{c|}{ Mass change [mg] } \\
\hline & & $\begin{array}{c}\text { Fe }+5 \\
\text { wt.\% } \\
\text { PEG }\end{array}$ & $\begin{array}{c}\text { Fe }+10 \\
\text { wt.\% } \\
\text { PEG }\end{array}$ & $\begin{array}{c}\text { Fe + 15 } \\
\text { wt.\% } \\
\text { PEG }\end{array}$ & $\begin{array}{c}\text { Fe + 5 } \\
\text { wt.\% } \\
\text { FEG }\end{array}$ & $\begin{array}{c}\text { Fe + 10 } \\
\text { wt.\% } \\
\text { PEG }\end{array}$ & $\begin{array}{c}\text { Fe + 15 } \\
\text { wt.\% } \\
\text { PEG }\end{array}$ \\
\hline 0 & 1153.8 & 1162.6 & 1176.0 & 1193.1 & 0 & 0 & 0 & 0 \\
\hline 1 & 1149.7 & 1153.0 & 1165.0 & 1180.1 & 4.1 & 9.5 & 11.0 & 13.0 \\
\hline 2 & 1148.6 & 1139.0 & 1148.0 & 1144.9 & 5.2 & 23.6 & 28.0 & 48.2 \\
\hline 3 & 1147.1 & 1125.2 & 1130.2 & 1137.1 & 6.6 & 37.4 & 45.8 & 56.0 \\
\hline 4 & 1130.0 & 1106.6 & 1110.7 & 1134.9 & 23.8 & 56.0 & 65.3 & 58.2 \\
\hline 5 & 1118.8 & 1089.8 & 1094.7 & 1121.8 & 35.0 & 72.8 & 81.3 & 71.2 \\
\hline 6 & 1112.6 & 1081.3 & 1081.6 & 1103.2 & 41.2 & 81.3 & 94.4 & 89.9 \\
\hline 7 & 1099.5 & 1078.2 & 1072.8 & 1090.3 & 48.1 & 84.3 & 103.2 & 102.8 \\
\hline 8 & 1097.5 & 1068.7 & 1064.9 & 1086.6 & 49.1 & 93.9 & 111.1 & 106.6 \\
\hline 9 & 1087.7 & 1054.4 & 1053.6 & 1077.8 & 49.5 & 108.2 & 122.4 & 115.3 \\
\hline 10 & 1105.7 & 1044.9 & 1041.7 & 1072.2 & 54.3 & 117.6 & 134.3 & 120.9 \\
\hline 11 & 1104.3 & 1044.7 & 1036.4 & 1065.2 & 56.3 & 117.7 & 139.6 & 127.3 \\
\hline 12 & 1104.7 & 1045.0 & 1034.2 & 1065.8 & 66.1 & 117.9 & 141.8 & 127.9 \\
\hline
\end{tabular}

Tab.4. The values of iron concentration in simulated body fluid after static immersion test.

\begin{tabular}{|c|c|c|}
\hline Time of immersion [week] & Sample & Concentration [mg/l] \\
\hline 4 & $\mathrm{Fe}$ & 780.48 \\
\hline 8 & $\mathrm{Fe}$ & 1560.97 \\
\hline 12 & $\mathrm{Fe}$ & 2243.90 \\
\hline 4 & $\mathrm{Fe}+5 \mathrm{wt} \%$ PEG & 211.38 \\
\hline 8 & $\mathrm{Fe}+5 \mathrm{wt} \%$ PEG & 357.72 \\
\hline 12 & $\mathrm{Fe}+5 \mathrm{wt} \%$ PEG & 650.40 \\
\hline 4 & $\mathrm{Fe}+10 \mathrm{wt.} \%$ PEG & 203.25 \\
\hline 8 & $\mathrm{Fe}+10 \mathrm{wt} . \%$ PEG & 406.50 \\
\hline 12 & $\mathrm{Fe}+10 \mathrm{wt} . \%$ PEG & 552.84 \\
\hline 4 & $\mathrm{Fe}+15 \mathrm{wt} . \%$ PEG & 284.55 \\
\hline 8 & $\mathrm{Fe}+15 \mathrm{wt} . \%$ PEG & 390.24 \\
\hline 12 & $\mathrm{Fe}+15 \mathrm{wt} . \%$ PEG & 1349.59 \\
\hline
\end{tabular}


Tab.5. The values of static corrosion rate for each material immersed in Hank's solution during 4,8 and 12 weeks.

\begin{tabular}{|c|c|c|c|c|c|}
\hline $\begin{array}{c}\text { Method of } \\
\text { calculation }\end{array}$ & $\begin{array}{c}\text { Time of } \\
\text { immersion } \\
\text { [week] }\end{array}$ & Fe & $\begin{array}{c}\text { Fe + 5 } \\
\text { wt.\% PEG }\end{array}$ & $\begin{array}{c}\text { Fe + 10 } \\
\text { wt.\% PEG }\end{array}$ & $\begin{array}{c}\text { Fe + 15 } \\
\text { wt.\% PEG }\end{array}$ \\
\hline $\begin{array}{c}\text { Corrosion rate } \\
\text { converted to the } \\
\text { specific surface area } \\
\text { [mg/m } 2 \text { day] }\end{array}$ & 4 & 1.535 & 2.174 & 2.221 & 0.628 \\
\cline { 2 - 6 } & 12 & 1.583 & 1.823 & 1.889 & 0.575 \\
\hline $\begin{array}{c}\text { Corrosion rate } \\
\text { calculated on the } \\
\text { weight of the } \\
\text { sample [mg/day] }\end{array}$ & 4 & 0.850 & 2.000 & 2.332 & 0.460 \\
\cline { 2 - 6 } & 12 & 0.877 & 1.677 & 1.984 & 1.904 \\
\hline
\end{tabular}

\section{CONCLUSION}

The iron based materials were prepared by powder metallurgy method and then coated with PEG layer using sol-gel process. The static immersion test was used to investigate of corrosion behaviour of iron-polymer samples. The results of the study showed that the polymer coating causes the desired increase in the degradation rate of carbonyl iron based porous structures. Increasing the corrosion rate of iron implant is desirable to allow the proliferation of bone tissue thereby restoring bone. Despite the fact that the PEG coating helped to improve the degradation of cellular samples obtained results are still not sufficient for some applications. And the process of degradation of porous iron material still needs to be adjusted in the light of accelerating.

\section{Acknowledgement}

This work was supported by the Projects VEGA 1/0074/17, APVV-0677-11, APVV-14-0103, and VVGS-PF-2016-72645.

\section{References}

[1] Grogan, JA., O’Brien, BJ., Leen, SB., McHugh, PE.: Acta biomater., vol. 7, 2011, p. 3523

[2] Williams, DF.: Biomaterials, vol. 29, 2008, p. 2953

[3] Rössig, C., Angrisani, N., Helmecke, P., Besdo, S., Seitz, JM., Welke, B., Reifenrath, J.: Acta biomater., vol. 25, 2015, p. 369

[4] Hermawan, H., Dubé, D., Mantovani, D.: Acta biomater., vol. 6, 2010, p. 1693

[5] Vieira, AC., Marques, AT., Guedes, RM., Tita, V.: Procedia Eng., vol. 10, 2011, p. 1602

[6] Schinhammer, M., Gerber, I., Hänzi, AC., Uggowitzer, PJ.: Mater. Sci. Eng. C, vol. 33, 2013, p. 782

[7] Hampp, C., Angrisani, N., Reifenrath, J., Bormann, D., Seitz, JM., Meyer-Lindenberg, A.: Mat. Sci. Eng. C, vol. 33, 2013, p. 326

[8] Chen, Y., Xu, Z., Smith, C., Sankar, J.: Acta biomater., vol. 10, 2014, p. 4573

[9] Zheng, YF., Gu, XN., Witte, F.: Mat. Sci. Eng. R, vol. 77, 2014, p. 34

[10] Liu, B., Zheng, YF., Ruan, L.: Mater. Lett., vol. 65, 2011, p. 540

[11] Duncan, R., Izzo, L.: Adv. Drug Deliver Rev., vol. 57, 2005, p. 2237

[12] Learmonth, ID.: Surgeon, vol. 1, 2003, p. 8 
[13] Chen, Q., Thouas, GA.: Mat. Sci. Eng. R, vol. 87, 2015, p. 1

[14] Bauer, S., Schmuki, P., von der Mark, K., Park, J.: Prog. Mater Sci., vol. 58, 2013, p. 261

[15] Park, J., Lee, S., Kang, S., Jeon, J., Lee, SH., Kim, HK., Choi, H.: Powder Technol., vol. 284, 2015, p. 459

[16] Reihanian, M., Asadullahpour, SR., Hajarpour, S., Gheisari, K.: Mater. Des., vol. 32, 2011, p. 3188

[17] Oriňaková, R., Oriňak, A., Kupková, M., Hrubovčáková, M., Markušová-Bučková, L., Giretová, M., Kal'avský, F.: Int. J. Electrochem. Sci, vol. 10, 2015, p. 8158 